\title{
SEA TEMPERATURES IN PLYMOUTH SOUND
}

\author{
By L. H. N. CoOper, D.Sc. \\ The Plymouth Laboratory
}

For ecological studies records of mean sea temperatures in and near Plymouth Sound are often required. The necessary data exist but have not been readily available in a convenient form.

Since 1898 sea temperature has been included amongst the observations made by the Plymouth City Meteorologist. In early days this was $\mathrm{Mr}$ Victor Prigg whose successors, Mr G. H. Ivory and Messrs G. H. Ivory and Partners continued the work until I954. In that year the work was transferred to the Department of the Medical Officer of Health for Plymouth. The measurements on the Fahrenheit scale appear always to have been made at a depth of $\mathrm{I}$ fathom $(\mathrm{I} \cdot 8 \mathrm{~m})$ at about the time of high water. They were made three times a week from the end of the Promenade Pier until it was destroyed by fire in March I94I and afterwards from the end of the 'Banjo Pier' until 1955. For the last two years they have been taken from the Pier Head of Millbay Docks, 0.3 nautical mile $(0.55 \mathrm{~km})$ distant. The three positions have a very similar exposure to the tidal stream and the observers by a series of comparable observations assured themselves that no appreciable error was introduced by the changes.

Five-year running means (anomalies in ${ }^{\circ} \mathrm{C}$ ) for air temperatures on Plymouth Hoe have been published by Southward \& Crisp (I954). In half a century they show a rise of more than $0.5^{\circ} \mathrm{C}$. Monthly means of many meteorological measurements on Plymouth Hoe have been published for many years in the Transactions of the Devonshire Association, but sea temperatures have not been included. Annual means of sea temperature have appeared somewhat erratically in the Annual Reports of the Medical Officer of Health. Monthly means, although prepared, have never been published except for the 8 years 1912-19 (Orton, 1920).

Mr E. Voaden of Messrs G. H. Ivory and Partners and Mr D. W. A. Cole of the Department of the Medical Officer of Health have generously provided us with the monthly means for each month from January 1947 to December 1956. Converted to the Centigrade scale they are printed here as Table I. For each month the Io-year mean has been computed. Monthly means averaged over the 55 years 1898 -1953 have also been provided by Mr Voaden. To facilitate future computing, they are reported on both scales of temperature (Table 2). During the years I9I2-I9 the months January-September were colder and the months October-December were markedly warmer than the 55-year mean. In the years 1947-56, ten of the monthly means are well above 
TABLE 1. MONTHLY MEAN SEA TEMPERATURES ( $\left.{ }^{\circ} \mathrm{C}\right)$ FOR PLYMOUTH SOUND 1947-1956 TOGETHER WITH MAXIMA AND MINIMA ATTAINED IN EACH MONTH

Jan. $\overbrace{\text { Feb. }}^{\text {Mar. }} \overbrace{\overbrace{\text { Mpr. }}^{\text {Apr. }}}^{\text {Mag }} \overbrace{\text { Man }}^{\text {May }}$

\begin{tabular}{|c|c|c|c|c|c|c|c|c|c|c|c|c|c|c|c|c|c|c|c|}
\hline \multirow[b]{2}{*}{ Year } & & & & & & & \\
\hline & Mean & Max. & Min. & Kean & Max. & Min. & Mean & Max. & Min. & Mean & Max. & Min. & Mean & Max. & Min. & Mean & Max. & Min. & \\
\hline 1947 & $\begin{array}{l}8 \cdot 3 \\
0.5\end{array}$ & 0.1 & 6.2 & $\begin{array}{l}5.3 \\
8.6\end{array}$ & 6.5 & $4 \cdot 3$ & 6.4 & $8 \cdot 3$ & $4 \cdot 7$ & $9 \cdot 6$ & II 6 & $8 \cdot 0$ & II $\cdot 2$ & $14 \cdot \mathrm{I}$ & 8.4 & $13 \cdot 6$ & $15 \cdot 3$ & & \\
\hline & $\begin{array}{l}9.5 \\
9.5\end{array}$ & & & $\begin{array}{l}8 \cdot 6 \\
0.2\end{array}$ & 9 & & & 9 & $\begin{array}{l}7 \\
8 \\
\end{array}$ & $\begin{array}{r}9.9 \\
90.4\end{array}$ & II & $8 \cdot 9$ & $12 \cdot 3$ & & & & & & \\
\hline $\begin{array}{l}\text { IS } \\
\text { IS }\end{array}$ & $\begin{array}{l}9.5 \\
9.4\end{array}$ & $\begin{array}{r}9 \cdot 9 \\
10 \cdot 2\end{array}$ & 8 & $\begin{array}{l}9 \cdot 3 \\
8 \cdot 4\end{array}$ & $9 \cdot 7$ & $\begin{array}{l}8.2 \\
7.8\end{array}$ & $\begin{array}{l}9.2 \\
0.2\end{array}$ & $\begin{array}{l}\text { IO.I } \\
\text { IO.I }\end{array}$ & 8 & $\begin{array}{l}\text { I0.4 } \\
\text { LO. }\end{array}$ & I & $9 \cdot 3$ & I. & & 7 & $14 \cdot 6$ & $I$ & & \\
\hline & $8 \cdot 2$ & & & & 8.2 & $\begin{array}{l}7.0 \\
7.6\end{array}$ & 8. & 10.1 & 7 & $\begin{array}{r}10.0 \\
8.9\end{array}$ & $\mathrm{I}$ & $\frac{4}{2}$ & & & 0 & & & & \\
\hline IS & 9 & 9.8 & $8 \cdot 1$ & $8 \cdot 2$ & 8.7 & $7 \cdot 7$ & 8. & 9 . & 7 & $9 \cdot 7$ & $\begin{array}{r}10.8 \\
\end{array}$ & 7.8 & & & $\begin{array}{r}9.5 \\
10.9\end{array}$ & $\cdot 7$ & $\begin{array}{l}4.7 \\
5.3\end{array}$ & {$[2 \cdot 3$} & \\
\hline & & 8.0 & & & 8.6 & 7.7 & & 9 & 8. & 0.6 & & 8.9 & & & 10.3 & & & & \\
\hline & 8 & II & & & & & & 9 . & 7. & $x \in$ & & 0.T & & & & & & & \\
\hline & 8 & & & & 8 & 6 & 6. & $7^{\circ}$ & 6. & 8.6 & & & & & & & & & \\
\hline 1956 & 0. & IO.I & 9 & & $9 \cdot 4$ & $6 \cdot 1$ & 7.9 & $8 \cdot 7$ & 7 & $9 \cdot 3$ & $9 \cdot 7$ & $8 \cdot 7$ & $\mathrm{II} \cdot 3$ & 12 & $9 \cdot 7$ & 3 & $13 \cdot 4$ & & \\
\hline \multirow{2}{*}{$\begin{array}{l}\text { ro-year } \\
\text { average }\end{array}$} & 8.95 & - & - & $7 \cdot 86$ & - & $\pi$ & $8 \cdot 21$ & - & - & $9 \cdot 60$ & - & - & II $\cdot 59$ & - & - & 13.78 & - & - & \\
\hline & \multicolumn{3}{|c|}{ July } & \multicolumn{3}{|c|}{ Aug. } & \multicolumn{3}{|c|}{ Sept. } & \multicolumn{3}{|c|}{ Oct. } & \multicolumn{3}{|c|}{ Nov. } & \multicolumn{3}{|c|}{ Dec. } & \\
\hline Year & Mean & 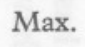 & n. & an & Max. & in. & ean & I & in. & Mean & $\Lambda$ & Sin. & Mean & $N$ & Min. & Mean & Max. & Min. & \\
\hline & & & & & & & & & & & & & & & $\mathrm{I} 2 \cdot \mathrm{I}$ & & & & \\
\hline & & & & & & & & & & & & & & & & & & & \\
\hline & & & & & & & & & & & & & & & & & & & 19 \\
\hline & & & & & & & & & & & & & & & & & & & $12 \cdot 2$ \\
\hline & & & & & & & & & & & & & & & & & & & I \\
\hline & & & & & & & & & & & & & & & & & & & \\
\hline & & & & & & & & & & & & & & & & & & & \\
\hline & & & & & & & & & & I4 & & & I & & Ic & & & & II .7 \\
\hline & & & & & & & $16 \cdot 4$ & & & I4. & I5 & $12 \cdot 8$ & & & II & & & I0.6 & II.9 \\
\hline 1956 & I $4 \cdot 6$ & 15.6 & $13 \cdot 7$ & I5. I & 15.5 & I 4.4 & 15.0 & 15.6 & $14 \cdot 2$ & $\mathrm{I} 4 \cdot 4$ & 15.4 & 13.3 & $12 \cdot 3$ & 13.3 & $\mathrm{II} \cdot 2$ & 10.6 & $\mathrm{II} \cdot 3$ & $9 \cdot 4$ & II $\cdot \varepsilon$ \\
\hline ear & 15.27 & - & - & $16 \cdot 22$ & - & - & $15.8 \mathrm{I}$ & - & - & I4.43 & - & - & $12 \cdot 26$ & - & - & 10.47 & - & - & 12. \\
\hline
\end{tabular}

TABLE 2. AVERAGE MEAN MONTHLY TEMPERATURES $\left({ }^{\circ} \mathrm{C}\right)$ OVER PERIODS OF YEARS

\begin{tabular}{|c|c|c|c|c|c|c|c|c|c|c|c|c|}
\hline & Jan. & Feb. & Mar. & Apr. & May & June & July & ug. & t. & Oct. & Nov. & D \\
\hline $\begin{array}{l}\text { ar average, }{ }^{\circ} \mathrm{F} \text {, } \\
\text { ar average, }{ }^{\circ} \mathrm{C} \text {, }\end{array}$ & $\begin{array}{r}47 \cdot 9 \\
8.8\end{array}$ & $\begin{aligned} 46 \cdot 5 \\
8 \cdot 0\end{aligned}$ & $46 \cdot c$ & & & 56 & $5 c$ & & & & & \\
\hline , & & & $7 \cdot 9$ & & II. & & & I5 & & 14 & & \\
\hline${ }^{\circ} \mathrm{C}, 1$ & 8.9 & $7 \cdot 8$ & $8 \cdot 2$ & $9^{\circ}$ & II & & & 10 & & I4 & $12 \cdot 2_{6}$ & \\
\hline 08 & -0. & -0. & $0.3+2$ & 0. & -0 & $-0^{\circ}$ & $-\varepsilon(2)$ & $p_{9}$ & 8 & & & \\
\hline C, $1947-56 f$ & & $\begin{array}{l}-0.2_{0} \\
+0.0_{3}\end{array}$ & $\begin{array}{l}-0.0_{7} \\
+0.2_{7}\end{array}$ & $\begin{array}{l}+0 . I_{6} \\
+0.6_{0}\end{array}$ & $\begin{array}{l}+0.2_{0} \\
+0.37\end{array}$ & $\begin{array}{r}0.0_{0} \\
+0.3_{4}\end{array}$ & $\begin{array}{l}-0.0_{6} \\
+0.2_{7}\end{array}$ & $\begin{array}{l}+0 . I_{6} \\
+0.2_{5}\end{array}$ & $\begin{array}{l}+0.22_{0} \\
+0.2_{2}\end{array}$ & -0.54 & & \\
\hline , $1947-50$ Irom I912 t & & & & & & & & & & & $-0.2_{6}$ & \\
\hline
\end{tabular}


the long-term average. If the exceptionally cold months of February and March I947 are omitted the monthly means for February and March for the remaining nine years were both also warmer than average. The years 1947-56 (even with February and March 1947 included) were on average warmer in every month than the years 1912-19. This trend is now well known to climatologists.

Atkins \& Jenkins (1952) have published monthly means for International Hydrographic Station E I ( $50^{\circ} 02^{\prime}$ N., $4^{\circ} 22^{\prime}$ W. $)$ and drew attention to some exceptional years. They presented no evidence for long-term changes. From the same observations I also sought evidence for long-term changes and failed to find it. The cruises are made about once a month, and there are inevitably many sources of bias in the raw data. A systematic study of the E I records which will stand statistical criticism will be tedious but needs to be made. Until this is done, the thrice-weekly records from Plymouth Sound provide a better basis for long-term ecological comparisons than do the monthly records from Station EI.

Of recent years there are indications that the composition of the fauna of the English Channel has changed due to an increase in the occurrence of southern, warmer-water forms. The rise of about $0.3^{\circ} \mathrm{C}$, found in Plymouth Sound, may well be a sufficient explanation: if it is, there is no point in seeking an explanation in other terms (as, for example, Cooper, 1955). I prefer to believe for the present that we have here interlocking facets of a global change and that the simple explanation by itself is not sufficient.

\section{SUMMARY}

Monthly mean sea-water temperatures in Plymouth Sound, prepared by the Plymouth City Meteorologist, are presented as data for ecological studies in this laboratory. In the last 40 years there has been a rise in mean temperature of about $0.3^{\circ} \mathrm{C}$.

\section{REFERENCES}

Atkins, W. R. G. \& Jenkins, P. G., I952. Note on sea temperatures in the English Channel, I92I to 1949, and Plymouth sunshine and light. F. mar. biol. Ass. U.K., Vol. 31, pp. 327-33.

COOPER, L. H. N., I955. Hypotheses connecting fluctuations in Arctic climate with biological productivity of the English Channel. Pap. mar. Biol. Oceanogr., DeepSea Res., Suppl. to Vol. 3, pp. 212-23.

ORTON, J. H., I920. Sea-temperature, breeding and distribution in marine animals. F. mar. biol. Ass. U.K., Vol. 12, pp. 339-66.

SOUTHWARD, A. J. \& CRISP, D. J., I954. Recent changes in the distribution of the intertidal barnacles Chthamalus stellatus Poli and Balanus balanoides L. in the British Isles. F. Anim. Ecol., Vol. 23, pp. 163-77. 